\title{
THE INFLUENCE OF DIFFERENCES STRATEGY, MARKET ORIENTATION, AND INNOVATION OF COMPETITIVE ADVANTAGES AND COMPANY PERFORMANCE (Empirical Study on Star Hotels in Semarang City)
}

\author{
Novita Lely Markus ${ }^{1}$ \\ Susilo Toto Raharjo ${ }^{2}$ \\ Mahfudz $^{3}$ \\ 1,2,3 Master of Management, Faculty of Economics and Business, Diponegoro \\ University
}

\begin{abstract}
This research aims to examine and analyze the influence of differentiation strategy, market orientation, and innovation in an effort to build a competitive advantage for the performance of the company improves on star hotels in the city of Semarang. The respondents in this research are the Manager of star hotels in the city of Semarang, the size of respondents in filling in the questionnaire is 63 (sixty-three) people. However, for some reason, 22 (twenty-two) respondents are not willing to do the filling out the questionnaires which resulted in the final sample size is 41 (forty-one) respondents.in this case, the tool used in the study is the analysis of Partial Least Square (PLS). Prior to testing the researchers first tested the questionnaire by means of the validity test and reliability test. Test validity is to see the questionnaire is valid or not, and the reliability test is meant to see the questions distributed reliable or not to do further testing. The empirical findings indicated that the differentiation strategy has a significant positive effect on competitive advantage; innovation has a significant positive effect on firm performance.
\end{abstract}

Keywords: differentiation strategy, market orientation, innovation, competitive advantage, firm performance.

\section{INTRODUCTION}

The growth of the accommodation business that continues to increase is due to the competition of business people in the accommodation sector continue to innovate in providing services and in providing facilities that can attract visitors who 
tend to want uniqueness and experience to enjoy the facilities at the hotel. In implementing a business strategy, it can certainly provide good results for the performance of the company, but if the selection of a business strategy that is not appropriate and not effective, the company will often fail.

Star hotels become one of the business sectors that have the characteristics of facilities and services, with a large market share and a broad segment of society, the competition that is often experienced is due to the decreasing purchasing power of consumers towards luxury products. Thus the company needs to start building a differentiation strategy from within as an effort to achieve competitive advantage and innovation that enables hotel managers to introduce new services that improve quality, so that both meet the changing needs of potential customers and increase their market share, sales and profits (Chen, Lin , \& Chang, 2009).

According to Kotler \& Armstrong (2003) differentiation is a process of designing a set of important differences in offering a different company from the competitors' offers. Companies that first enter the market using a differentiation strategy will be considered as a top priority, which has the wisdom to apply prices and exploit a broad market segment in pursuit of profit and high growth. The advantage through differentiation strategies can be achieved through good product quality and an emphasis on innovation as the spearhead of the company. According to Potter (2008), innovation is one way for companies to gain competitive advantage and improve company performance. However, many managers are not fully aware of the value of service innovation as a competitive advantage in making investment decisions.

Competitive advantage is defined as a strategy that can reciprocate the company's cooperation in competing to be more successful in market share (Porter, 2008). A strategy is designed to create sustainable competitive advantage, so that old markets and new markets can be dominated by companies. Identifying tangible and intangible assets of a company that makes the company unique is important in order to achieve the success of the strategy adopted. According to Cesar et al., (2016) organizational performance can be measured by comparing the results of the organization with its competitors, considering the dimensions of the quality of goods and/or services offered such as profitability with new products; return on investment and assets; operating costs, and overall performance.

\section{LITERATURE REVIEW}

Company performance is a description of the success of a company to achieve its goals and can be measured based on objective ability and perception (Hoque \& James, 2000). In a company that is based on accounting and finance, in 
addition to performance measures that use accounting methods, the tendency of number manipulation from management is also the cause of invalid measurements. Then the subjective use of measures based on managers' perceptions, will be an option to anticipate if the objective performance data in a study is not available (Beal, 2000). According to Rue \& Ibrahim (1998), Tsamenyi, Onumah, \& Tetteh-Kumah (2010), Fraj-Andrés, Martinez-Salinas, \& Matute-Vallejo (2009) three indicators that make up the company's performance variables are sales growth, profit growth, share market (market share), and asset growth.

Barney (1991) stated that competitive advantage is an effort by a company to be able to create a difference in the acquisition of benefits for its customers who buy products or services with more value compared to its competitors. According to Edwards, Evanchik, Renda-tanali, \& Kahn, n.d. (in Alfadda, 2010) indicators of competitive advantage variables include social legitimacy, organizational learning, and management ability.

According to Daft (2003) differentiation strategy is a type of competitive strategy used by the organization to differentiate the company's products and services compared to other companies in the same industry. Or a differentiation strategy is the activity of designing a unique series that intends to distinguish what a company has to offer with what a competitor has to offer. According to Kotler (2008), differentiation strategies provide different offers with four indicators namely product differentiation, service differentiation, personnel differentiation, and image differentiation.

Market orientation is also called the implementation of marketing concepts (Gray et al. 2002). Market orientation is defined as organizational behavior that identifies consumer behavior, competitor behavior distributes market information to the entire organization and responds with coordination, profit calculation. According to Zhou, Brown, \& Dev (2009), Hult \& Ketchen (2001), and Shehu \& Mahmood (2014) argue that for measuring market orientation variables there are three indicators used namely customer orientation, competitor orientation, and interfunctional orientation.

Innovation is the management of all activities related to the process of creating ideas, developing technology, creating and marketing new products, processes, manufacturing or equipment (Trott \& Paul, 2008). So innovation is a combination of all processes (Kotler \& Armstrong, 2003). To create innovation, companies need to create an internal environment that facilitates a culture of innovation characterized by flexibility and speed of change in response to new opportunities (Urbancova, 2013). According to (Chukwunonso, Omoju, Ikani, \& Ribadu, 2011) there are 3 things that need to be considered in the application of innovation, namely: the process of innovation, product innovation, and organizational development. There 
are similarities and differences between researchers and other researchers. The research equation carried out in this study is to analyze the influence of differentiation strategies, market orientation, and innovation on competitive advantage and company performance in star hotels in the city of Semarang.

Research on the impact of the differentiation strategy on competitive advantage found that differentiation strategy is a competitive type of strategy to be used in differentiating the company's products and services from its competitors, which aims to achieve competitive advantage from business competitors because one or more competing companies feel depressed will see opportunities to improve their position (Daft, 2003; Cater, Tomas, Pucko, 2005; Teeratansirikool, 2012).

\section{H1: Differentiation strategies have a positive effect on Competitive Advantage}

To be able to satisfy consumer desires, planning and coordination among all parts contained in the organization is an effective way to gain and maintain excellence by paying attention to market orientation (Supranoto, 2009; Afsharghasemi, Zain, Sambasivan, \& Ng Siew Imm, 2013).

\section{H2: Market orientation has a positive effect on competitive advantage}

Innovative is a tendency that comes from new ideas open as an aspect of organizational culture, with the results of innovation capacity derived from the company's ability to successfully adopt or implement new ideas, processes and products (Hurley and Hult, 1998 in Andiyanto, 2017). In the era of knowledge development, innovation is the main source of competitive advantage (Daghfous, 2004). Successful innovation can support long-term business performance and maintain excellence because it can make the company's external environment more difficult to imitate the strategies used (Teece, 2007; Gracia-Morales et. Al. 2007).

\section{H3: Innovation has a positive effect on competitive advantage}

Two different concepts of competitive advantage are companies must focus on managerial strategies in achieving goals and maintaining a position of competitive advantage from its competitors, because the position of competitive advantage will lead to superior company performance (Ma, 2000). As in the research of Kuo, Lin, and Shan Lu (2016) in container shipping companies in Taiwan, the competitive advantage also positively influences the company's performance.

\section{H4: Competitive advantage has a positive effect on company performance}

According to Cater, Tomas; Pucko (2005) in his research which identified the basic forms of competitive advantage of companies in Slovenia at the end of the transition process and analyzed the relationship between forms of competitive advantage and company performance. The results show by building competitive advantage over differentiation than lower prices (costs) in Slovenian companies that companies with 
a competitive advantage in differentiation are more successful than companies with a competitive advantage at lower prices (costs). The conclusion is that companies with simultaneous competitive advantage are only in one of two forms, as well as a competitive advantage in matters that are discussed more strongly reflected in better corporate performance.

H5: Differentiation strategies have a positive effect on company performance

Zahra and Das (1993) in Andiyanto (2017) argue that through innovation as a unique product and creating value for customers can help the company to highlight the excellence of its corporate performance Zahra and Das (1993) in Andiyanto (2017). An innovative way to protect the market so that company performance can survive well can be done with new products or with a different process from other products. In the study by Saunila (2014) stated that the higher aspects of the capability of the company's innovation capability, the greater the financial performance and operational performance of the company.

\section{H6: Innovation has a positive effect on company performance}

\section{RESEARCH METHOD}

This study shows how the variables to be tested can be measured precisely. For this reason, a concept boundary is needed. Measurement is closely related to the problem of data validity and also concerns the problem of variable indicators that are operationalized. There are five variables that are developed in this study namely Company Performance, Competitive Advantage, Product Differentiation, Service Differentiation, Personnel Differentiation, and Image Differentiation. Table 1 show the research variables and definition of indicator that used in this research.

In this study as the use of data analysis with Partial Least Square (PLS) analysis, namely the equation of the Structural Equation Modeling (SEM) model based on components or variants. PLS is also referred to as a powerful analysis method with soft modeling because the assumption of the data does not have to be on a measurement scale, data distribution and can be used in a small number of samples or under 100 samples (According to Ghozali, 2008).

Covariance-based SEM generally tests causality/theory while PLS is a more predictive model. PLS can also be used to explain whether there is a relationship between latent variables, which can also analyze constructs formed by reflective and formative indicators. 


\section{Table 1}

Research Variables and Definition of Indicators

\begin{tabular}{|c|c|c|c|}
\hline No. & Variable & $\begin{array}{c}\text { Operational and Source } \\
\text { Definition }\end{array}$ & Indicators \\
\hline 1. & Company performance & $\begin{array}{l}\text { Company performance is a } \\
\text { description of the success of a } \\
\text { company to achieve its goals and } \\
\text { can be measured based on } \\
\text { objective ability and perception } \\
\text { (Wang, 2008; Hoque and James, } \\
\text { 2000) }\end{array}$ & $\begin{array}{l}\text { According to Barkham et al. } \\
\text { (1996), Rue and lbrahim } \\
\text { (1998) and Szimansky } \\
\text { (2000) indicators of company } \\
\text { performance variables } \\
\text { include: } \\
\text { 1. Sales growth } \\
\text { 2. Profitability } \\
\text { 3. Market share } \\
\text { 4. Increased assets }\end{array}$ \\
\hline 2. & Competitive Advantage & $\begin{array}{l}\text { According to Utterback (1994), } \\
\text { Bresser and Millonig (2003) } \\
\text { competitive advantage is a unit } \\
\text { position developed by the company } \\
\text { through a pattern of how to explore } \\
\text { its resources to create advantages } \\
\text { over its competitors }\end{array}$ & $\begin{array}{l}\text { According to Bashir Al-Fadda } \\
\text { (2010) indicators of } \\
\text { competitive advantage } \\
\text { variables include: } \\
\text { 1. Social legitimacy } \\
\text { 2. Organizational learning } \\
\text { 3. Management capabilities }\end{array}$ \\
\hline 3. & $\begin{array}{l}\text { Differentiation } \\
\text { Strategy }\end{array}$ & $\begin{array}{l}\text { Differentiation is the act of } \\
\text { designing a series of meaningful } \\
\text { differences to differentiate a } \\
\text { company's offer from a competitor's } \\
\text { offering (Kotler \& Armstrong, 2003). }\end{array}$ & $\begin{array}{l}\text { Indicators of differentiation } \\
\text { strategy variables are: } \\
\text { 1. Product differentiation } \\
\text { 2. Differentiation of services } \\
\text { 3. Differentiation of personnel } \\
\text { 4. Image differentiation } \\
\end{array}$ \\
\hline 4. & Market Orientation & $\begin{array}{l}\text { Market orientation is defined as } \\
\text { organizational behavior that } \\
\text { identifies consumer needs, } \\
\text { competitor behavior distributes } \\
\text { market information throughout the } \\
\text { organization and responds with } \\
\text { coordination, calculation of profits } \\
\text { (Gary et al, 2002). }\end{array}$ & $\begin{array}{l}\text { According to Zhou et. al. } \\
\text { (2009), Hult \& Ketchen } \\
\text { (2001), Alizadeh et. al } \\
\text { (2013), and Shehu \& } \\
\text { Mahmood (2014) argue that } \\
\text { there are three indicators } \\
\text { used for measuring market } \\
\text { orientation variables, } \\
\text { including } \\
\text { 1. Customer orientation, } \\
\text { 2. Competitor orientation, } \\
\text { and } \\
\text { 3. Inter-functional orientation. }\end{array}$ \\
\hline 5. & Innovation & $\begin{array}{l}\text { Innovation is creativity that has } \\
\text { commercial value to utilize existing } \\
\text { products and create new and } \\
\text { valuable products (Porter, } 1990 \text { in } \\
\text { Siagian, 2017). }\end{array}$ & $\begin{array}{l}\text { According to Chukwunonso } \\
\text { and Franklyn (2011), there } \\
\text { are } 3 \text { things that need to be } \\
\text { considered in implementing } \\
\text { innovation, namely: } \\
\text { 1. Innovation process, } \\
\text { 2. Service innovation, and } \\
\text { 3.Organizational } \\
\text { development. }\end{array}$ \\
\hline
\end{tabular}




\section{DATA ANALYSIS AND DISCUSSIONS}

Data processing techniques using the SEM based Partial Least Square (PLS) method require 2 stages to assess the Fit Model from a research model. The first, evaluation of the outer model or measurement model is how each indicator block relates to the latent variable as a valid measure of whether or not a measuring instrument is reliable and whether questionnaire questions are distributed to respondents for further testing (Ghozali, 2006).

After evaluating the measurement model and found that each construct has met the convergent validity requirements, discriminant validity, and composite reliability, the next is a structural model testing to see R-Square, constituent relationships, and significance values of the research model. The structural model is evaluated using R-Square for dependent constants of the t-test and the significance of the coefficient of structural path parameters.

Table 2

R-Square Value

\begin{tabular}{|c|c|}
\hline & R-Square \\
\hline Competitive Advantage & 0,541 \\
\hline Company Performance & 0,500 \\
\hline
\end{tabular}

Table 2 is show the result of the influence of independent variables on Competitive Advantage (CA) with a value of 0.541 with an explanation that $54.1 \%$ variable Competitive Advantage (CA) and the remaining $45.9 \%$ is the contribution of other variables not examined, while the value of Company Performance (CP) is equal to 0.500 with an explanation that $50 \%$ variable Company Performance (CP) and the remaining $50 \%$ is the contribution of other variables not examined. So there are still many variables outside the model in research that can be added to future research.

Table 3

Significance Testing Results

\begin{tabular}{|l|c|c|c|c|c|}
\hline & $\begin{array}{c}\text { Original } \\
\text { sample } \\
\text { estimation }\end{array}$ & $\begin{array}{c}\text { Mean of } \\
\text { subsamples }\end{array}$ & $\begin{array}{c}\text { Standard } \\
\text { deviation }\end{array}$ & $\begin{array}{c}\text { T - } \\
\text { Statistic }\end{array}$ & P Values \\
\hline DS->CA & 0,675 & 0,701 & 0,164 & 4,106 & 0,000 \\
\hline MO->CA & 0,238 & 0,256 & 0,223 & 1,067 & 0,287 \\
\hline In->CA & $-0,166$ & 0,203 & 0,230 & 0,721 & 0,471 \\
\hline CA-CP & 0,280 & 0,294 & 0,181 & 1,545 & 0,123 \\
\hline DS->CP & 0,023 & 0,020 & 0,254 & 0,092 & 0,926 \\
\hline In->CP & 0,488 & 0,486 & 0,203 & 2,406 & 0,016 \\
\hline
\end{tabular}


Table 3 is show the magnitude of the coefficient level of Differentiation Strategy (DS) variable to Competitive Advantage (CA) is equal to 0.675 with the statistical value of the Differentiation Strategy (DS) variable on Competitive Advantage (CA) is 4.377, the value of the coefficient variable of Market Orientation (MO) on Competitive Advantage (CA) is 0.238 with the statistical value of Market Orientation (MO) variable on Competitive Advantage (CA) is 1.048, the value of the Innovation (In) variable coefficient level on Competitive Advantage (CA) is -0.166 , with the statistical value of the Innovation (In) variable against Competitive Advantage (CA) is 0.705 .

Coefficient value of Competitive Advantage (CA) variable on Company Performance (CP) is 0.280 with the t-statistic value of Competitive Advantage (CA) variable on Company Performance is 1.580 , the coefficient value of Differentiation Strategy (DS) variable on Company Performance is 0.213 with the t-statistic value of Differentiation Strategy variable (DS) on Company Performance is 1.087, the coefficient value of the Innovation (In) variable on Company Performance (CP) is 0.441 with the $\mathrm{t}$-statistic value of the Innovation (In) variable on Company Performance is 2.116. Can be seen significant if the t statistic value is greater than the value of $t$ table ( $t$ count $>t$ table). The value of $t$ table with a significance of $5 \%$ is 1.96 .

\section{CONCLUSIONS AND SUGGESTIONS}

The conclusion of the six hypotheses proposed in this study, based on the results of the analysis and discussion that has been carried out are as follows:

1. Differentiation strategies have a significant positive effect on competitive advantage. Understanding and implementing the right differentiation strategy will create or give a better competitive advantage to the company.

2. Market orientation has no significant positive effect on competitive advantage. the level of the role of market orientation activities or processes does not necessarily have an effect on the company in maintaining a competitive advantage.

3. Innovation has a significant negative effect on competitive advantage. The low organizational development and creativity of ideas that are part of the source of innovation in star-rated hotels in the city of Semarang have no effect on the company in achieving a good competitive advantage.

4. Competitive advantage has no significant positive effect on competitive advantage. the level of influence of competitive advantage does not necessarily provide better corporate performance results. 
5. Differentiation strategies have a positive and not significant effect on company performance. With a high differentiation strategy, it is not necessarily an influence for the company to achieve good company performance as well.

6. Innovation has a significant positive effect on competitive advantage. High perceptions of innovation can provide better company performance.

\section{Suggestions}

1. Subsequent research needs to add the sample size of respondents. So that by increasing the size of the sample it is recommended to get more diverse information.

2. Future research with the discussion of the same topic as this research is about the performance of companies in star hotels, it is suggested to add research variables, or use other variables that have not been used for research in this study so that the results can help improve company performance.

3. The population size used in this study is only a little because further research is expected to increase the number of samples that will be used, so that it will approach the picture of results that are closer to the actual conditions.

\section{REFERENCES}

Afsharghasemi, A., Zain, M., Sambasivan, M., \& Ng Siew Imm, S. (2013). Market Orientation, Government Regulation, Competitive Advantage and Internationalization of SMEs: A Study in Malaysia. Journal of Business Administration Research, 2(2), 13-22. https://doi.org/10.5430/jbar.v2n2p13

Alfadda, B. (2010). Institutional renewal and adaptation (IRA): Creating and managing sustainable competitive advantage (SCA). ProQuest Dissertations and Theses, $124 \quad-\quad$ n/a. Retrieved from http://search.proquest.com/docview/899758960?accountid=10297\%5Cnhttp:// sfx.cranfield.ac.uk/cranfield?url_ver=Z39.88-

2004\&rft_val_fmt=info:ofi/fmt:kev:mtx:dissertation\&genre=dissertations+\&+the ses\&sid=ProQ:ABI/INFORM+Global\&atitle=\&title=Institutional+rene

Cater, Tomas;Pucko, D. (2005). How Competitive Advantage Influences Firm Performance: the Case of Slove. Economic and Business Review for Central and South - Eastern Europe, 7(2), 119-135.

Cesar, J., Guimarães, F. De, Andrea, E., Charles, E., Dorion, H., \& Olea, P. M. (2016). Author's Accepted Manuscript The use of organizational resources for 
product innovation and organizational performance: A survey of the Brazilian furniture industry Reference: Intern. Journal of Production Economics. https://doi.org/10.1016/j.jpe.2016.07.018

Chen, Y. S., Lin, M. J. J., \& Chang, C. H. (2009). The positive effects of relationship learning and absorptive capacity on innovation performance and competitive advantage in industrial markets. Industrial Marketing Management, 38(2), 152158. https://doi.org/10.1016/j.indmarman.2008.12.003

Chukwunonso, F., Omoju, J. O., Ikani, D., \& Ribadu, M. B. (2011). Management of Information Technology for Competitive Advantage: A Savvy Case Study. Journal of Scientific Research, 1(2), 121-129.

Daghfous, A. (2004). Absorptive Capacity and The Implementation of Knowledgeintensive Best Practices. SAM Advanced Management Journal, 69 (2), Pp.21-27.

Edwards, K., Evanchik, M. A., Renda-Tanali, I., \& Kahn, R. (N.D.). Institutional Renewal And Adaptation ( Ira ): Creating And Managing Sustainable Competitive Advantage ( Sca ) By Bashir Alfadda Submitted to the Graduate faculty of University of Maryland University College In Partial Fulfillment of The Requirements for $t$.

Fraj-Andrés, E., Martinez-Salinas, E., \& Matute-Vallejo, J. (2009). A multidimensional approach to the influence of environmental marketing and orientation on the firm's organizational performance. Journal of Business Ethics, 88(2), 263-286. https://doi.org/10.1007/s10551-008-9962-2

Hoque, Z., \& James, W. (2000). Linking Balanced Scorecard Measures to Size and Market Factors: Impact on Organizational Performance. Journal of Management Accounting Research, 12(1), 1-17. https://doi.org/10.2308/jmar.2000.12.1.1

Hult, G. T. M., \& Ketchen, D. J. (2001). Does market orientation matter?: A test of the relationship between positional advantage and performance. Strategic Management Journal, 22(9), 899-906. https://doi.org/10.1002/smj.197

Rue, L. W., \& Ibrahim, N. A. (1998). The Relationship between Planning Sophistication and Performance in Small Businesses. Journal of Small Business Management, (1993), 24-33. https://doi.org/Article 
Shehu, A. M., \& Mahmood, R. (2014). Influence of Entrepreneurial Orientation and Business Environment on Small and Medium Firm Performance: A PLS Approach. Advances in Management \& Applied Economics, 4(4), 101-114.

Teeratansirikool, L. (2012). Competitive strategies and firm performance: the mediating role of performance measurement. https://doi.org/10.1108/17410401311295722

Tsamenyi, M., Onumah, J., \& Tetteh-Kumah, E. (2010). Post-privatization performance and organizational changes: Case studies from Ghana. Critical Perspectives on Accounting, 21(5), 428-442. https://doi.org/10.1016/j.cpa.2008.01.002

Urbancova, H. (2013). Competitive Advantage Achievement through Innovation and Knowledge. Journal of Competitiveness, 5(1), 82-96. https://doi.org/10.7441/joc.2013.01.06

Zhou, K. Z., Brown, J. R., \& Dev, C. S. (2009). Market orientation, competitive advantage, and performance: A demand-based perspective. Journal of Business Research, 62(11), 1063-1070. https://doi.org/10.1016/j.jbusres.2008.10.001 